University of Chicago Law School

Chicago Unbound

Journal Articles

Faculty Scholarship

2014

\title{
Why Do Countries Adopt Constitutional Review?
}

Tom Ginsburg

Mila Versteeg

Follow this and additional works at: https://chicagounbound.uchicago.edu/journal_articles

Part of the Law Commons

\section{Recommended Citation}

Tom Ginsburg \& Mila Versteeg, "Why Do Countries Adopt Constitutional Review?," 30 Journal of Law, Economics and Organization 587 (2014).

This Article is brought to you for free and open access by the Faculty Scholarship at Chicago Unbound. It has been accepted for inclusion in Journal Articles by an authorized administrator of Chicago Unbound. For more information, please contact unbound@law.uchicago.edu. 


\title{
University of Virginia School of Law
}

Public Law and Legal Theory Research Paper Series 2013-29

\section{Why Do Countries Adopt Constitutional Review?}

\author{
Tom Ginsburg \\ University of Chicago Law School \\ Mila Versteeg \\ University of Virginia School of law
}

September 2013

This paper may be downloaded without charge from the Social Science Research Network Electronic Paper Collection:

http://ssrn.com/abstract=2319363

A complete index of University of Virginia School of Law research papers is available at Law and Economics: http://www.ssrn.com/link/U-Virginia-LEC.html

Public Law and Legal Theory: http://www.ssrn.com/link/U-Virginia-PUB.html 


\title{
Why Do Countries Adopt Constitutional Review?
}

\author{
Tom Ginsburg \\ University of Chicago Law School \\ Mila Versteeg \\ University of Virginia School of Law
}

In recent decades, there has been a wide-ranging global movement towards constitutional review. This development poses important puzzles of political economy: Why would self-interested governments willingly constrain themselves by constitutional means? What explains the global shift towards judicial supremacy? Though different theories have been proposed, none have been systematically tested against each other using quantitative empirical methods. In this paper we utilize a unique new dataset on constitutional review for 204 countries for the period 1781-2011 to test various theories that explain the adoption of constitutional review. Using a fixed effects spatial lag model, we find substantial evidence that the adoption of constitutional review is driven by domestic electoral politics. By contrast, we find no general evidence that constitutional review adoption results from ideational factors, federalism, or international norm diffusion.

JEL Codes: K00, K19, K49 


\section{Introduction}

Constitutional review, the ability of judges to supervise the constitution, has spread around the world in recent decades. By our account, some $38 \%$ of all constitutional systems had constitutional review in 1951; by $2011,83 \%$ of the world's constitutions had given courts the power to supervise implementation of the constitution and to set aside legislation for constitutional incompatibility. Thus, what Alexis de Tocqueville once described as an American peculiarity is now a basic feature of almost every state (De Tocqueville 1835: 72-77).

The spread of this institution poses an important puzzle in political economy: Why would self-interested governments willingly constrain themselves by constitutional means? And why would democratic majorities restrict their future political choices by putting their faith in the hands of unelected judges? What underlies this radical global move toward "judicialization" or “juristocracy” (Hirschl 2004; Gardbaum 2009)?

Several theories have been proposed to explain this phenomenon. Early theoretical accounts were federalist or ideational in character. Some argued that constitutional review arose to respond to governance problems such as federalism, or the need to coordinate among multiple branches of government (Shapiro 1999). Ideational accounts instead emphasized the importance of rights protection and the rule of law, or the need to be protected from the vagaries of government action (Cappelletti 1989). More recent work has proposed strategic explanations, in which constitutional review is conceptualized as a response to the domestic electoral market (Ginsburg 2003; Hirschl 2004; Finkel 2008; Stephenson 2003; Erdos 2010). When constitution-makers foresee losing power after constitutional adoption or revision, they are more likely to institute constitutional review, as the judiciary may protect the substantive values that the drafters will be unable to vindicate through the political process. Constitutional review, in this account, is a form of "political insurance," through which constitution-makers safeguard their future political interest (Ginsburg 2003). In addition, there is a recent but growing literature on cross-national diffusion of constitutional norms, which suggests that provisions might be adopted in response to constitutional developments in foreign states (Goderis and Versteeg 2011; Law and Versteeg 2011; Dixon and Posner 2011; Elkins 2009). 
If constitutional norms diffuse, so might constitutional review, as drafters seek to achieve conformity with international norms (Stone Sweet 2008).

While there is no lack of theories, little is known in an empirical and systematic way about the origins and evolution of constitutional review on a global scale. None of the theories have been systematically tested against each other using quantitative empirical methods, and in particular, there has been almost no effort to apply theories of norm diffusion to the adoption of constitutional review. This article takes up these challenges. Drawing on an original dataset on 204 countries since 1781, we are in a unique position to empirically document the historical trajectory of constitutional review. We then use this data to test which of the theories appear to provide the best explanation for the spread of constitutional review around the globe over the past two centuries.

We find that the adoption of constitutional review is best explained by domestic politics, and in particular, uncertainties in the electoral market. More specifically, we find that electoral competition, as measured by the difference between the proportion of seats held by the first and second parties in the legislative branch, predicts the adoption of constitutional review. This phenomenon, we find, is present in autocracies and democracies alike.

While we find empirical support for the theory that constitutional review is adopted as a form of political insurance, we do not find robust evidence to support theories of transnational diffusion, or the idea that constitutional review is adopted in response to previous adoption by other states. We only find some evidence of diffusion in the sub-sample of democratic regimes, but do not find a diffusion effect in the full sample of countries. This finding has implications for the literature on norm diffusion. Recent work has revealed substantial evidence of diffusion in the realm of constitutional rights (Goderis and Versteeg 2011). Our findings suggest that the structural part of the constitution is less prone to foreign and international influence than is the bill of rights. This dichotomy arguably follows from the fact that structural provisions such as constitutional review are likely to have more direct effects on the political and institutional interests of constitution-makers, while rights provisions can be a relatively inexpensive way of signalling conformity to international norms (Cope 2013). Only democracies-regimes that may genuinely 
want to constrain themselves by constitutional means - are susceptible to following international norms regarding the adoption of constitutional review.

The remainder of this paper is organized as follows. Part 2 provides a brief account of the origins and spread of constitutional review. Part 3 reviews the leading theories that have been offered to explain the spread of this institution. Part 4 describes our data and methodology, while Part 5 presents our main results. Part 6 discusses sensitivity analyses and the potential endogeneity of our findings. Part 7 concludes.

\section{The Origins and Global Spread of Constitutional Review}

Constitutional review, which we define as the formal power of a local court or court-like body to set aside or strike legislation for incompatibility with the national constitution, has spread rapidly around the world in recent decades. ${ }^{1}$ This power, which Alexis de Tocqueville once deemed to be "peculiar to the American magistrate," is now a standard feature of most of the world's constitutions (De Tocqueville 1835: 72-77). As Figure 1, Panel A, depicts, constitutional review was non-existent in 1781 but has steadily gained popularity over the next 230 years, such that $83 \%$ of the world's constitutions now include it.

[COMP: insert figure 1 here]

Constitutional review originated in the American colonial charters and state constitutions, which were used by colonial judges to disapply laws even before the establishment of the federal government (Prakash and Yoo 2003). The U.S. Constitution is not explicit about whether federal courts have the power to strike down statutes incompatible with the Constitution, but many scholars believe that the founding fathers assumed this would be the case (Snowiss 1990; Treanor 2005). Indeed, Alexander Hamilton (1788) famously devoted much of Federalist 78 to justifying the practice. $^{2}$ After Marbury v. Madison, 5 U.S. 137 (1803), there was no doubt that the federal courts could disapply federal statutes, though, for many years, courts devoted most of their energy to 
invalidating state statutes. Even if it was seldom exercised against national legislation, the power's existence was well-recognized by the mid-nineteenth century (De Tocqueville 1835: 28).

The American model of constitutional review is characterized by decentralized review exercised at every level of the judiciary, with a Supreme Court at the top. An important feature of this model is that review takes place only in a concrete dispute, or a "case or controversy." Several Latin American countries adopted a similar form of constitutional review in the $19^{\text {th }}$ century. ${ }^{4}$ It became the dominant form of constitutional review in the early $20^{\text {th }}$ century, and remains a common mode of constitutional review today.

In contrast with this American model, a growing number of countries today have centralized constitutional review power in a specialized constitutional court, while denying the rest of the judiciary the power to void legislation. This centralized model of constitutional review has its origins in the work of the great Austrian legal theorist Hans Kelsen, who used it in his design for the 1920 Constitution of the Austrian First Republic. Ordinary judges, in Kelsen's view, were servants of the law, and their task was limited to applying it (Kelsen 1928, as discussed in Stone Sweet 2012). Judges should not be empowered to make law, nor could they properly determine the constitutionality of legislation. This view squarely falls within the civil law tradition which, building on Montesquieu, envisions a strict division of labor between three branches of government, rather than a system of checks and balances in which the different branches not only collaborate, but also compete with each other (Merryman and Perez-Perdomo 2007). In order to preserve legislative sovereignty (and the traditional conception of separation of powers) as much as possible, Kelsen designed a special and more explicitly political body called a Constitutional Court, whose members were appointed for life by the legislature to adjudicate constitutional disputes (chiefly those involving Austrian federalism).

This kind of centralized review is often "abstract": the constitutional court does not resolve concrete cases between two litigating parties but answers constitutional questions referred to it by elected government officials, either before or after the adoption of a law. In addition to abstract review, many constitutional courts may also review concrete disputes, typically constitutional questions referred to it by the judiciary in the course of ordinary litigation. Ordinary proceedings are 
suspended until the constitutional court has ruled on the constitutionality of the statute in question. Once the constitutional court has decided, its ruling will serve as the basis for the referring court's decision (e.g., Austria Const. art. 89 (1920)). ${ }^{5}$

The Kelsenian model of constitutional review was soon adopted in other countries, including Czechoslovakia (Const. art. 54.13 (1920)), Liechtenstein (Const. art. 104 (1921)), and Iraq (Const. art. 83 (1925)), ultimately finding a place in the Basic Law of post-war Germany. Whereas the Austrian model only provided for limited jurisdiction of certain disputes, the German model introduced the device of the constitutional complaint, in which any individual could complain about the constitutionality of a statute or government action, even without a specific case or controversy. This new mechanism played an important role in democratizing access to the constitutional court, and associating the institution with the protection of rights. An essentially similar institutional arrangement, but one without direct constitutional complaint, is found in Italy (Ferejohn and Pasquino 2004; 2012). Constitutional courts of the Kelsenian type were adopted throughout Europe during the third wave of democracy (for example in Portugal 1976, Spain 1978, and the former Soviet bloc after the cold war).

Another model of centralized constitutional review is associated with the 1958 Constitution of France, and was transposed to many French colonies that gained independence shortly thereafter (Favoreu 1990; Stone Sweet 1992). The Conseil Constitutionnel was a specially designated body that heard challenges to legislation from a limited number of governmental actors before legislation was promulgated. Over time, however, the French model has evolved, and constitutional amendments in 2008 expanded jurisdiction to include post-promulgation review as well as prepromulgation review. In short, the version of constitutional review in France has evolved to become much closer to the German variant. ${ }^{6}$

Figure 1, Panel B, depicts the popularity of the decentralized and centralized models among the countries that have judicial review in their constitution. It shows that while the decentralized U.S. model used to be dominant, the specialized constitutional court is slightly more popular today. Because our theories of constitutional review adoption do not depend on the type of review at issue, 
the remainder of this paper will use a composite indicator of constitutional review, which includes both centralized and decentralized types.

\section{Theories of the Adoption of Constitutional Review}

What explains the rapid spread of this institution, which was considered exceptional and theoretically problematic into the early twentieth century? The literature has proposed different theoretical explanations for why countries adopt constitutional review. We categorize these as ideational, coordination and commitment, electoral market, and diffusion theories. ${ }^{7}$ In this section, we briefly survey these theories and translate them into testable hypotheses. These theories are explored in more detail in our earlier work (see e.g., Ginsburg 2003; Goderis and Versteeg 2011; Law and Versteeg 2011; Galligan and Versteeg 2013).

\section{A. Ideational Theories}

Early accounts of constitutional review adoption focused on ideas that generate a local demand for constitutional review. The ideational story of judicial review adoption focuses on the association between constitutional review and rights (Cappelletti 1989. For an overview see Hirschl 2014). As Ran Hirschl $(2014,158)$ articulates, one of the core premises of the ideational story is that a "mature democracy," in Ronald Dworkin's (1990) words, must protect itself from the tyranny of the majority through judicial protection of rights provisions that protect vulnerable groups and individuals (Weinrib 2007; Elster 1993). The key juncture for this theory is often traced back to World War II: fascist atrocities demonstrated the potential dangers of unconstrained democracy, causing Europeans to begin to doubt the merits of parliamentary sovereignty in the post war period (Zakaria 2003: 17). The horrors of the war, moreover, provided an impetus for the development of an international human rights regime (Simmons 2009; Henkin et al. 2009), and more generally, induced a growing rights-consciousness around the globe. This growing awareness of rights, which is often portrayed as a bottom-up demand by the people and a genuine reflection of popular will (Hirschl 2014), led countries to embrace a more mature version of democracy, which included constitutional review to constrain the majority (Cappelletti 1989). 
Yet ideational accounts of the association between constitutional review and rights must grapple with the fact that the founding cases of constitutional review occurred well before World War II and did not emphasize rights early on. Therefore, in a competing ideational account, Shapiro (1999) discusses what he calls the "rule-of-law" theory, suggesting that constitutional review will flourish in countries with stronger allegiances to the rule-of-law and the liberal ideal of limited government. Because the English common law tradition emphasized these ideas (Hayek 1960; Mahoney 2001), English colonies were particularly receptive environments for judicial review. However, other countries with a strong rule-of-law tradition, such as Germany with its longstanding Rechtstaat tradition, would also be likely to find constitutional review attractive (Shapiro 2002).

\section{B. Coordination and Commitment Theories}

In addition to ideational theories, there are also more functional explanations for constitutional review adoption, which we characterize as involving coordination and commitment (for an overview see Hirschl 2014). One set of explanations regards constitutional review adoption as a solution to coordination problems involving the separation of powers and multi-level governance (Choper 1980). The persistence and stability of complex governance in multi-layered systems requires coordination (Garrett and Weingast 1993), which can be facilitated by an independent and apolitical judiciary to serve as an impartial arbiter in disputes concerning the scope and nature of the fundamental rules of the political game. Such a need for judicial review is particularly pronounced in federalist countries (Shapiro 1999), which by definition feature multiple levels of law-making. Indeed, the early systems in which constitutional review was most effective, including those in the United States, Austria, and later, Australia and Canada, were all federal systems, suggesting that there may be a link between federalism and the existence of constitutional review (Shapiro 1999; Weingast 1995). ${ }^{8}$

A second set of theories suggests that judicially enforceable limits on government may be instrumental to economic growth by facilitating investment (see, for example, La Porta et al. 1998, Mahoney 2001, Acemoglu and Johnson 2005: 953). In a classic article, Douglass North and Barry Weingast (1989) demonstrate that successful commitment devices allowed the government to 
credibly commit to property rights and improved its position in capital markets. Commitment theory suggests that constitutional limits on the government -including those enforced through constitutional review - help ensure that capital will be protected, and will thus spur economic growth.

\section{Electoral Market Theories}

A different set of theories, electoral market theories, grounds the adoption of constitutional review in domestic political logics. It has long been established that constitutional courts should be understood as an integral part of the larger political setting, and cannot be explained independently from it (Dahl 1991; Shapiro 1964). Taking this logic as a starting point, Ginsburg (2003) argues that the spread of constitutional review is driven by demand for political insurance. Constitutional review, he argues, is a solution to the problem of political uncertainty at the time of constitutional design. Parties who fear losing power in the future are likely to prefer constitutional review by an independent court because the court provides an alternative forum for challenging government action and mitigates the risk of electoral loss (Ginsburg 2003; see also Ramseyer 1994; Stephenson 2003; Finkel 2008; Erdos 2010; Magealheas 2013). On the other hand, stronger political parties will have less desire for independent constitutional review because they anticipate successfully advancing their interests in the post-constitutional legislature (Stephenson 2003; Chavez 2004). Political fragmentation, Ginsburg finds, is associated with constitutional review.

Hirschl (2004) offers a complementary political account of judicialization, which he calls hegemonic preservation. His view is that judicialization, including establishment of constitutional review, is a strategy adopted by elites who foresee losing power. Hirschl's account is squarely focused on the crucial issue of the timing of the adoption of review (Hirschl 2004; Hirschl 2013). In the final stages of their rule, elites who foresee themselves losing power set up courts to preserve some of their substantive values by placing them outside the realm of ordinary law-making (Hirschl 2004). For example, Mexico empowered its Supreme Court in the waning years of PRI rule, presumably to protect its agenda (Finkel 2008; Magaloni 2008). ${ }^{9}$ Hirschl and Ginsburg's theories are similar in that they both rely on intertemporal electoral uncertainty as the primary theoretical driver 
for the adoption of constitutional review. Hirschl's hegemonic preservation focuses on declining powers, while Ginsburg's insurance also accounts for new, non-hegemonic, political parties' support for establishing constitutional review when those parties foresee post-constitutional electoral failure. Both insurance and hegemonic preservation theses, then, are rooted in exogenously specified domestic political incentives.

\section{Diffusion Theories}

A final set of theories are those drawn from the literature on policy diffusion. The basic intuition of this literature is that the more countries adopt a particular policy or institution, the more likely others are to follow (Strang 1991). Existing research suggests that countries are influenced by each other in establishing independent central banks (Polillo and Guillén 2005), adopting neoliberal policies (Simmons and Elkins 2004), environmental policies (Frank et al. 2000) and establishing democracy (Gleditsch and Ward 2006), among other things. Recent work has also found evidence of transnational diffusion in the realm of constitutional rights (Goderis and Versteeg 2011; Law and Versteeg 2011). It is possible that the same logic applies to the adoption of constitutional review: the more countries adopt constitutional review, the higher the probability that others will do the same.

The diffusion literature has proposed a wide range of mechanisms through which transnational diffusion may take place, "ranging from Bayesian learning to rational competition through hegemonic domination to unthinking emulation of leaders" (Simmons et al. 2006). Each of these mechanisms relies on a distinct logic of why countries would follow each other, and who borrows from whom (Simmons and Elkins 2005; see also Elkins et al., 2006). Goderis and Versteeg (2011) conceptualize diffusion in the constitutional realm and suggest that constitutional provisions might diffuse as a result of four distinct mechanisms: (1) coercion, (2) economic competition, (3) learning, and (4) acculturation. The first mechanism, coercion, suggests that powerful states, such as aid donors or former colonizers, push for the adoption of specific constitutional arrangements in less powerful states. As an example, the independence constitutions of Britain's former colonies in Africa and the Caribbean were drafted and negotiated by Britain, which insisted upon the inclusion of a bill of rights modelled after the European Convention on Human Rights (Parkinson 2007: 1-19). 
In a similar fashion, the United States directed the writing of the 1935 constitution of the Philippines (Billias 2010) and the 1986 constitution of Micronesia (Tamanaha forthcoming), while more recently it exerted pressure during the writing of the 2005 Iraqi Constitution (Feldman 2005).

The logic of the second diffusion mechanism, competition, suggests that states strategically copy particular constitutional arrangements in order to attract foreign trading partners and investors (Goderis and Versteeg 2011; Law 2008). The more countries successfully attract investment by adopting specific constitutional rules, the more others are likely to follow, producing a "race to the top" (Law 2008). As an example, the Sadat regime in Egypt realized that its socialist and nationalist policies put the nation at a comparative disadvantage as potential investors feared expropriation. The regime therefore created an independent constitutional court mandated to uphold the constitution's anti-expropriation guarantee (Moustafa 2007: 67-70).

The third mechanism, learning, entails a functional borrowing of constitutional provisions among states that share important pre-existing qualities, such as a similar legal system. Where states have information that certain constitutional features are successful in other states that they consider to be peers, they may decide to follow that example. As an example, the drafters of the 1922 Irish constitution translated and carefully considered all pre-existing constitutions in Western nations and extensively debated their potential application to the Irish case (Brady forthcoming).

The last diffusion mechanism, acculturation, suggests that states emulate foreign constitutional rules not because they are convinced by the intrinsic merits of these rules, but to gain international acceptance and legitimacy (Goodman and Jinks 2004; Meyer and Rowan 1977; DiMaggio and Powell 1983; Meyer et al. 1997). Once a critical number of states adopt a certain constitutional rule, this rule may become a global script of the international community (or "world society" in the parlance of sociologists). In order to be accepted into world society, states must conform to these global constitutional scripts (de Wet 2006; Bobbitt 2002). As an example, when South Sudan established itself as an independent state in 2011, it adopted a constitution with human rights provisions that largely conformed to international norms (Cope, 2013).

As Goderis and Versteeg (2011) acknowledge, it is often impossible to distinguish these mechanisms from each other empirically, or to establish whether a state is indeed "learning," 
"acculturating", or perhaps adopting foreign constitutional provisions for some other reason. Nonetheless, these mechanisms do help us in conceptualizing the more specific channels through which diffusion might take place. In the case of constitutional review, we expect that the most important determinant of diffusion is whether states share colonial ties. Many colonial powers exercised strong influence over independence constitutions adopted in their former colonies, which also affected their arrangements on constitutional review (Go 2003). Most of the French former colonies adopted the French style constitutional council, for example, while many of the former British colonies retained the Privy Council as the highest court to exercise constitutional review (Voigt et al. 2007; Go 2003). Other plausible determinants of the diffusion of constitutional review include a shared language, a shared religion and geographic proximity, all of which are standard channels in the policy diffusion literature (Goderis and Versteeg 2011).

\section{Data and Methodology}

We now turn to the empirical analysis, in which we test the central research question of this paper: why do countries adopt constitutional review? Specifically, we develop quantitative measures for each of the theories set forth in the previous section and test whether any of these accounts are supported by statistical evidence.

\section{A. The Empirical Model}

To explain why countries adopt constitutional review, we estimate the following probit model:

$P\left(y_{i t}=1 \mid y_{i t-1}=0, \sum_{j \neq i}\left(W_{i j t-1} \times y_{j t-1}\right), X_{i t}\right)=F\left(\rho \sum_{j \neq i}\left(W_{i j t-1} \times y_{j t-1}\right)+\beta X_{i t}+\alpha_{i}+\delta_{t}\right)$

where $y_{i t}$ is a binary variable that captures whether or not a country $i$ has adopted constitutional review at time $t$. We use this model to explain the "onset" of constitutional review, or the presence of constitutional review conditional upon the absence of constitutional review in the previous year. 
Thus, the aim of our analysis is to explain why countries adopt constitutional review, not why they retain constitutional review after adoption.

$F$ denotes the cumulative distribution function of the standard normal distribution, so that we use standard probit maximum likelihood techniques to estimate the parameters of the model. $X_{i t}$ is a set of explanatory variables that captures possible domestic determinants of constitutional review, as conceptualized by the ideational, multi-level governance, and electoral market theories described in the previous section. $\sum_{j \neq i}\left(W_{i j t-1} \times y_{j t-1}\right)$ is a set of "spatial lags" that capture the weighted average incidence of constitutional review in other countries $j \neq i$ (see Goderis \& Versteeg 2011). The weights $W_{i j t-1}$ correspond to the relative connectivity from country $j$ to country $i$ in year $t-1$ along different dimensions of space (e.g., shared language, shared colonizer). The variable $y_{j t-1}$ captures the presence of constitutional review in country $j$ in the previous year $t-1{ }^{10}$ Thus, the "spatial lags" capture the prevalence of constitutional review in other countries, while recognizing that some foreign countries are more important than others, and so given higher weights in the analysis.

$\alpha_{i}$ is a set of country fixed effects, which are included to control for observed and unobserved country characteristics that do not vary over time. ${ }^{11}$ Such characteristics might include whether or not a country has a common law legal heritage or has a particular religious tradition, for example. The fixed effects also deal with a form of omitted variable bias that is specific to the diffusion literature, which is the difficulty of distinguishing true interdependence from "common shocks," also known as "Galton's problem" (Franzese and Hays 2008). When countries are subject to the same domestic shocks, they may experience a "parallel evolution" (Simmons et al. 2006, 787-89). In our context, this might involve a pattern wherein all countries independently adopt constitutional review because they are subject to similar domestic developments, such increased political competition, without regard to external developments. Without inclusion of the fixed effects, the spatial lags may capture a parallel evolution rather than true spatial interdependence. $\delta_{t}$ is a set of cubic polynomials, $t, t^{2}$ and $t^{3}$, which are used to account for time, or the growing likelihood of constitutional review adoption as the country grows older. ${ }^{12}$ Finally, to account for 
heteroskedasticity and the correlation of error terms over time, we compute robust standard errors clustered at the country level.

\section{B. Data Collection}

\section{Constitutional Review}

Our data on constitutional review comes from the Comparative Constitutions Project (CCP). In particular, for every national constitution ever written since 1781 we coded whether or not the constitution mandates a local court or court-like body to set aside or strike legislation for incompatibility with the national constitution. This definition distinguishes transnational courts of review, such as the European Court of Justice, the Court of Justice of the Common Market for Eastern and Southern Africa (COMESA), and the Caribbean Court of Justice, which are charged with interpreting international treaties (Cf. Stone Sweet 2000; Dixon and Jackson 2012). ${ }^{13}$ Conversely, it also excludes systems in which review is limited to examining the compatibility of international treaties with the constitution (Niger Const. art 55 (1960)). In addition, it excludes systems in which review is limited to executive action rather than legislation. Our definition of constitutional review is a formal one: it only takes into account the power of review as written down in a nation's constitution. Of course, we realize that there is a wide range of variation in the degree to which courts around the world are actually able to use their mandate. Yet the strength and independence of any given court is notoriously hard to measure, and we believe that our study of the formal mandate will nevertheless offer important insights into government's motivations to adopt constitutional review.

In operationalizing our definition of constitutional review, we consider several difficult coding cases. British Commonwealth countries present particular challenges because in some countries the decision by the court is not final and binding. As is well known, the United Kingdom has long followed a tradition of parliamentary sovereignty, in which the courts have no general power over legislation (Dicey 1915). This changed somewhat with the adoption of the Human Rights Act 1998, under which local courts perform a limited review for compatibility with the 
European Convention of Human Rights (Bogdanor 2009). This is a kind of constitutional review, though it is one in which parliament retains the option of legislating contrary to the Human Rights Act, so long as it is clear about doing so. Similarly, the Canadian Charter of Rights and Freedoms allows provincial legislatures to legislate notwithstanding a court decision that the act infringes the Charter (Art. 36 (1982)). These are examples of the so-called "new commonwealth model" of constitutional review, or "weak-form" review (Gardbaum 2001; Tushnet 2003; Erdos 2010). We consider the Canadian case, based as it is on the local constitution, to be a case of constitutional review, though we do not treat the UK system as such. ${ }^{14}$

The Privy Council is more problematic. After formal independence from England, many commonwealth jurisdictions retained the possibility of appeal from the final court in the jurisdiction to the Judicial Committee of the Privy Council in London in cases involving the interpretation of the Constitution (Trin. \& Tobago Const. art. 80(1)(c) (1962)). This body, which dates from 1833, retains appellate jurisdiction in some form for several different jurisdictions (Voigt et al. 2007). ${ }^{15}$ In this sense it is a form of transnational review, but one that is based on the local legal order. No doubt, extra-territorial review functioned to reassure audiences of the quality of the legal system in the early years of independence (Voigt et al. 2007). The drafting of many of these constitutions was carried out in a similar fashion, and we observe close similarities in provisions in many of these cases. ${ }^{16}$ In the regression analyses that follow, we opt to include the Privy Council as a form of constitutional review. ${ }^{17}$

We also should define what we mean by a court or court-like body. The key factor for us is that the institution be staffed by judges or justices without significant executive or legislative representation. Of course, many appointment mechanisms to constitutional courts depend on the action of executive or legislative agencies. But if the body is primarily staffed with executive or legislative officials, we do not consider it a court. For example, in many systems with a tradition of parliamentary sovereignty, a legislative body is charged with ensuring constitutionality of legislation. In China, for example, the Standing Committee of the National People's Congress interprets the constitution (Const. art. 67(1) (1982)). Similarly, in the Constitution of Equatorial 
Guinea 1968, the Upper House is charged with ensuring constitutionality. We do not consider these to be cases of judicial review for our purposes.

On the other hand, partial membership by non-jurists does not disqualify the institution in our view. In the French tradition, the Conseil Constitutionnel includes the former presidents of the republic as a formal matter, currently Valery Giscard d'Estaing, Jacques Chirac and Nicholas Sarkozy. But the majority of the members of the Conseil have judicial or legal experience. ${ }^{18}$ Given that it also uses court-like procedures, we treat this body as exercising the power of constitutional review (Stone Sweet 1992; 1995; 2000).

Another problem comes from constitutions that do not expressly provide for constitutional review. Most famously, the U.S. Constitution omits any direct mention of the power, though as noted above, scholars widely believe that the founders intended the courts to have it (Snowiss 1990; Treanor 2005). The United States is not alone in this respect. The Australian Constitution does not expressly mention constitutional review (partly because the drafters used the American Constitution as a model; see Billias 2010), but constitutional review has long been considered an "axiomatic" part of the legal system (Foley 2007). While the Australian High Court had long exercised the power, it was not until Australia ended its relationship with the Privy Council in 1987 that the High Court began to assert itself with great vigor. ${ }^{19}$ Our approach excludes the small number of cases, chiefly the United States and Australia, whose constitutions do not explicitly provide for constitutional review power, even though courts exercise the power in practice. $^{20}$

Following these rules, we collected information on constitutional review for 204 different countries (including some that have ceased to exist). ${ }^{21}$ In the remainder of this section, we explain how we operationalize the different theories of judicial review adoption, and which explanatory variables are included in the model.

\section{Ideational and Multilevel Governance Theories}

Having discussed our dependent variable, we will next discuss how we operationalize the various theories. Ideational theories that link constitutional review to popular attitudes about rights are difficult to quantify, and there is no generally-recognized cross-national measure of rights- 
consciousness. $^{22}$ (Of course, to the extent that any country's rights-consciousness is stable over time, the country fixed effects in our model will control for it.) We capture ideational theories that link constitutional review to a rule-of-law tradition (Shapiro 1999) with a new legal infrastructure index created by Nardulli et al (2011). This index includes country-level data on the number of legal publications published and the number of law schools that are open in any given year. Our assumption is that the more law schools that are open and the more legal publications being produced in any given country, the more a rule-of-law culture has taken hold, since more legal infrastructure indicates greater importance of law in society. We weight these measures according to population size, so that they capture the number of legal publications and law schools per capita. ${ }^{23}$ This data is available for the period 1800-2011. ${ }^{24}$

For the theories that link constitutional review to the existence of potential governance problems in a multi-layered federal system, we use data from the PolityIII data project to construct a variable that captures whether any given country, in any given year, possesses a federal system (Gurr et al. 1990). ${ }^{25}$

To capture the link between economic development and judicial review as posited by the commitment theory, we use a variable that captures energy consumption per capita, developed initially by Singer et al (1973) and updated by the Correlates of War dataproject. ${ }^{26}$ We use this measure rather than GDP per capita because it is available from 1816 onwards, while GDP data only becomes available in the 1950s. Since the pairwise correlation between energy consumption per capita and GDP per capita is 0.57 for the post 1950s period, we believe that energy consumption is a good proxy for economic development in the earlier period. ${ }^{27}$

\section{Electoral Theories}

To quantify political insurance theory as conceptualized by Ginsburg (2003), we use data from Henisz (2002) on the party composition of the legislative branch of government to construct a variable that captures the difference between the proportion of seats held by the first and second largest parties in the lower house of the legislative branch. Specifically, we construct the political

insurance variable as follows: $\frac{P_{1}}{T S}-\frac{P_{2}}{T S}$, where $P_{1}$ is the number of seats held by the largest party in 
the lower house of the legislature, $P_{2}$ the number of seats held by the second largest party in the lower house of the legislature and $T S$ is the total number of seats in the legislature. ${ }^{28}$ We predict that this variable will be negativey correlated with the onset of judicial review.

In creating the political insurance measure, we are confronted with two issues. First, we have to decide whether to restrict the analysis to democracies. Ginsburg's political insurance theory was developed in the context of democracies, and the logic of purchasing political insurance in the face of electoral competition does not necessarily carry over to the autocratic context. In autocracies, one party may hold all seats in the legislative branch of government, and the political insurance variable would take value 1. At the same time, constitutional review has been adopted by democratic and undemocratic regimes alike. Specifically, over the course of the full time period covered in our analysis, $40 \%$ of all autocratic regimes (and $67 \%$ of all democratic regimes) had constitutional review in their constitution. Today, no less than $77 \%$ of all autocratic regimes have judicial review in their constitution - a lower proportion than democracies but still a significant percentage. If we were to reduce the sample to democratic countries only, we would miss a substantial part of the variance in constitutional review adoption around the world. In addition, a large and growing literature suggests that institutions such as legislatures, courts and elections do matter in autocracies (Schedler 2009; Ginsburg and Moustafa 2008; Levitsky and Way 2010). So-called "electoral authoritarians" (Schedler 2009) are by definition unlikely to be entirely insulated from electoral pressures. If an autocratic leader foresees losing power, or a transition to a somewhat more competitive (though not necessarily democratic) electoral system, the regime may adopt constitutional review as a form of political insurance. (This is the logic of Hirschl's complementary model of hegemonic preservation.) For these reasons, we opt to initially include autocratic regimes in our analysis, but also to repeat our analysis for a sub-sample of democratic regimes only.

Second, we have to decide how to treat possible information that constitution-makers have concerning the future composition of the legislative branch. A contemporaneous measure of party composition might be an imperfect measure of electoral politics, because political parties might already have expectations concerning the make-up of the political landscape following the next election, which might change their views on the desirability of constitutional review. We opt to 
initially use a contemporaneous insurance measure for our analysis, but also experiment with alternative measures that capture the difference between the proportion of seats held by the first and second largest parties in the lower house of the legislature one and four years after the constitution has been adopted. ${ }^{29}$

\section{Diffusion Theories}

To capture the influence of the constitutional decisions of foreign countries, we construct a set of so-called "spatial lags." As discussed above, each spatial lag captures the weighted average incidence of constitutional review in other countries. What distinguishes the different spatial lags from each other is the weighting: each spatial lag is weighted according to a different dimension of space (e.g., geography, language).

To test diffusion through colonial ties, we construct a binary indicator that captures whether any two countries ever shared a common colonizer and interact it with a variable that captures constitutional review adoption. Thus, the spatial weight links all Britain's former colonies to each other, ${ }^{30}$ while the resulting spatial lag captures judicial review adoption by all foreign countries to which any given country is linked through colonial ties. ${ }^{31}$ To test diffusion through a shared language, we construct a binary measure that captures whether any two countries share a common official language, and again use it to construct a spatial lag that captures constitutional review adoption by all countries with which any given country shares the same language. ${ }^{32}$ To test diffusion through a shared religion, we construct a binary measure that captures whether any two countries share a common dominant religion (Barro and McCleary 2005) and use it to construct a spatial lag that captures constitutional review adoption by all countries with which a country shares a common dominant religion. ${ }^{33}$ Finally, to test diffusion through geographic proximity, we construct a variable that captures whether any pair of countries shares a common border and construct a lag that captures constitutional review adoption by neighboring countries. ${ }^{34}$ Table 1 lists all the variables used in estimation along with their minimum, maximum, mean and standard deviations. $^{35}$

[COMP: Insert Table 1 here] 


\section{Main Empirical Findings}

When testing the various explanatory theories against each other, we find that political insurance is a statistically significant and substantively important determinant of constitutional review adoption, but find limited support for the other theories.

To test the determinants of judicial review adoption, we use the fixed effects probit model specified in equation (1) as our benchmark specification. Because not all variables discussed in the previous section are available for the full sample period, we first estimate the specification including only those variables for which we have the largest coverage across time and space, namely the spatial lags and the insurance variable. These are also our main variables of interest. Table 2, column 1, reports the marginal effects for this specification. ${ }^{36}$ The results suggest that the political insurance variable is a statistically significant predictor of constitutional review adoption at the 5\% confidence level. Its effect is negative, which means that the larger the difference in the proportion of seats held by the first and second party of the legislative branch, the less likely a country is to adopt constitutional review. This supports the political insurance hypothesis: the more uncertainty there is about which party will hold power in the future, the more likely the constitution is to establish constitutional review.

We next consider the size of this effect. The marginal effects of the insurance variable reported in Table 2 capture the change in the probability of constitutional review adoption in a given year in percentage points if the political insurance variable goes from 0 to 1 (or from a system in which competing parties hold to the same number of seats to a one-party system). In such a scenario, the probability of constitutional review adoption decreases by 0.9 percentage points. In the more realistic scenario in which the strongest party in the legislative branch sees a 10 percentage point gain in the number of seats it holds (from the mean of 83 percent), the probability of constitutional review adoption decreases by 0.09 percentage points in the given year. To further appreciate the size of this effect, these numbers can be evaluated against a "baseline probability" of adoption, which is the probability of adoption when all predictor variables are evaluated at their

sample means. ${ }^{37}$ This baseline probability of adoption is 0.5 percent in each year, which means that, 
ceteris paribus, over the course of a twenty-year period, the probability that the average country adopts constitutional review is 12.4 percent. $^{38}$ But when the proportion of seats held by the first party increases by 10 percentage points, the probability of judicial review adoption decreases from 0.5 percent to 0.41 percent in each year. As a result, over a twenty-year period, the probability of adoption becomes 10.3 percent, a decrease of 2.1 percentage points relative to the baseline. While this effect might appear to be modest at first, it becomes more sizable over time.

[COMP: Enter Table 2 here]

While domestic politics matters, international norms, values, and considerations do not seem to have significant effects. Table 2, column 1 shows that none of the spatial lags that capture transnational diffusion theory turn out to be statistically significant predictors of constitutional review adoption. Nor are they jointly significant. ${ }^{39}$ This is an important finding for the literature on policy diffusion, as it suggests that the adoption of constitutional review follows a different logic than the adoption of constitutional rights. Previous research by Goderis and Versteeg (2011) shows that bills of rights are inherently transnational documents, shaped by the constitutional choices of foreign states. Our findings suggest that this logic does not carry over to the choice of the institution typically tasked with enforcing the bill of rights. A possible explanation for this finding is that rights are "cheap talk," or a low-cost way of paying lip service to international norms (Law and Versteeg 2012c), whereas institutional structures are adopted primarily because of local considerations.

In order to maximize the number of observations in our sample, we have so far only considered the spatial lags and the political insurance variable. However, as discussed in the previous section, political insurance and transnational diffusion are not the only possible explanations for constitutional review adoption. To test whether other theories hold any explanatory power, we next augment the baseline specification of Table 1, column 1 with four additional variables: (1) the number of law schools per capita (capturing the rule-of-law theory); (2) the number of legal publications per capita (also capturing rule-of-law theory); ${ }^{40}$ (3) whether or not a country possesses a federal system (capturing functional theories of coordination); ${ }^{41}$ and (4) energy 
consumption per capita (capturing commitment theories that link constitutional review to economic development). The results are reported in Table 2, column 2. When re-estimating the baseline specification with these four variables included, the number of legal publications per capita is a positive and statistically significant predictor at the 10 percent confidence interval. This finding lends some weak support for the rule-of-law theory. ${ }^{42}$ None of the other variables, by contrast, are statistically significant predictors of constitutional review adoption. At the same time, the insurance effect is still negative and significant at the 5 percent confidence level, while the spatial lags are again not statistically significant. Because our main interest is in diffusion and political insurance, and because these additional variables reduce the number of observations by almost 30 percent, we use the specification reported in Table 2, column 1 as the basis for further analysis.

We next explore whether there might be a difference between democratic and nondemocratic countries. Our initial expectation is that political insurance will be stronger in democratic regimes, since competition between two or more parties is one of the defining features of a democracy. At the same time, our data reveals that constitutional review is not confined to democratic regimes, but instead, is a common feature of democracies and autocracies alike. At the same time, as we noted above, autocrats may not be completely immune from the electoral market; if the balance of power shifts, and the dominant party foresees future electoral loss, it might adopt constitutional review to secure its interests downstream.

We expect that the logic of diffusion theory is particularly applicable to autocratic regimes. Autocrats with poor human rights records might adopt constitutional review to pay lip service to the norms of the international community (Law and Versteeg 2012c, but see Linos 2011; Linos 2013). Especially when autocrats expect that they will be able to control the court, constitutional review might boost the regime's international reputation without imposing any real costs.

To explore whether there exist differences between democratic and non-democratic regimes, we re-estimate the baseline specification reported in Table 2, column 1 for two subgroups of democracies and autocracies, respectively. ${ }^{43}$ The results are presented in Table 2, columns 3 and 4. ${ }^{44}$ Perhaps surprisingly, the results show that the political insurance variable is negative and statistically significant for both democratic and autocratic regimes alike (cf. Ginsburg and Moustafa 
2008). Thus, both for the sub-group of democracies and autocracies, the probability of constitutional review adoption increases when the difference between the proportion of seats held by the first and second largest party becomes smaller. This finding suggests that autocratic regimes are not immune to the workings of the electoral market.

Somewhat contrary to our expectations, we find evidence of diffusion in democratic regimes, but not in autocratic regimes. The results, reported in Table 3, columns 3 and 4, show that democracies follow the lead of countries with whom they share a common colonizer or with whom they share a religion, although the size of the effects are very small. These findings suggest that autocratic regimes do not simply adopt constitutional review to secure international approval. Constitutional courts, after all, may impose genuine constraints on autocratic leaders after their adoption (see Ginsburg and Moustafa 2008). Democracies, by contrast, turn out to be more susceptible to international norms, possibly because such norms align with pre-existing internal preferences of democratic citizens. To the extent that constitutional review brings future political costs, democracies might be more willing to bear these than autocracies. ${ }^{45}$

The analysis so far has not taken account of the fact that the decision to adopt constitutional review may be informed by expectations for the future. Political players may already have expectations about the future make-up of the political landscape, even when this is not yet reflected in our data. Specifically, they may foresee an electoral loss before elections have actually taken place. In fact, a key feature of electoral market theories (including the political insurance and the hegemonic preservation theory) is that political players act based on expectations for the future. Players are likely to adopt constitutional review when they expect to be faced with increased competition, not when they have already facing such competition. To test the extent to which expectations for the future affect our analysis, we re-estimate the findings from Table 2, column 1 while lagging the political insurance so that it captures the political composition one and four years later, respectively. The results from these specifications are reported in Table 2, columns 5 and 6. They show that, when using these alternative measures, the effect of the political insurance variable becomes both larger and more significant than in the specification with the contemporaneous insurance variables. This suggests that parties are able to anticipate, to a certain degree, electoral 
outcomes down the road, and to make institutional choices based on the expected outcomes. However, the forward lagged insurance variables are likely to be endogenous; it is possible that the electoral composition of the legislative branch at $t+1$ and $t+4$ has already been affected by the presence of constitutional review (or any of the other variables in our model). Moreover, these measures assume that actors have perfect information about the electoral make-up of the legislature, which is likely to be an unrealistic assumption. For that reason, we opt to use the contemporaneous measure in our baseline specifications.

\section{Robustness and Endogeneity}

In this section, we examine the extent to which the results are robust to alternative model specifications. We also discuss issues of causality.

All the results reported so far are based on a fixed effects probit model. However, as described in more detail in note 11, the fixed effects probit model potentially suffers from an “incidental parameters" problem, that is, for a fixed number of within-group observations and a growing number of groups (which means: more countries entering the sample, and hence more fixed effects), the fixed effects cannot be estimated consistently. At the same time, studies have shown that with a sufficiently large time series, the resulting bias becomes negligible, and that any bias only affects the coefficients, but not the marginal effects (Fernandez-Val 2009). To nonetheless explore whether the incidental parameters problem may affect our results, we re-estimate the specification reported in Table 1, column 1 using a fixed effects linear probability model (see Goderis \& Versteeg (2011) and Miguel et al. (2004)). Results are reported in Table 3, column 1. Again, the political make-up of the legislature is a negative and statistically significant predictor of constitutional review adoption at the 5 percent confidence level. The size of the effect appears to be slightly larger than found in the probit model. Should the strongest party in the legislature gain 10 percent more seats, the probability of constitutional review adoption decreases by 0.36 percentage points in each year. ${ }^{46}$ 
While the results from the fixed effects LPM are similar to the fixed effects probit model, one potential downside of the LPM is that it does not take into account the binary nature of the dependent variable, as a result of which predicted values may fall outside the 0 to 1 interval. $^{47}$ Wooldridge (2002) notes, however, that the LPM is often a convenient approximation of the probit or logit model, and, more specifically, that its performance improves the more the explanatory variables are binary (or the more "saturated" the model is). In our case, most of our explanatory variables are either binary or bounded between 0 and 1, which suggests that the LPM estimates are likely to be a good approximation of the probit model.

However, because neither the fixed-effects probit model nor the fixed-effects linear probability models are entirely free of potential econometric problems, we also experiment with two alternative models: (1) a fixed effects conditional logit model and (2) a random-effects probit model. $^{48}$ The results from both of these models (the coefficients and marginal effects of which are reported in Table 3, columns 2 and 3, respectively) are fairly similar to our original findings. ${ }^{49}$ However, both the conditional logit and the random effects probit models come with their own distinct set of problems, and so neither serves as an ideal baseline model for our analysis. In particular, the coefficients produced by the conditional logit model do not lend themselves to substantive interpretation, while the random effects probit model does not fully take into account unobserved cross-country heterogeneity. The fact that both of these models produce results that are very similar to our original specification suggests that our findings are unlikely to be an artefact of model selection.

We next explore what happens if we exclude the country fixed effects altogether, and estimate a simple probit model that does not take account of cross-country heterogeneity. While the LR-statistic for unobserved heterogeneity (reported in Table 2) indicates that unobserved country heterogeneity is a concern for our analysis, the fixed specifications take out all cross-sectional variation and may leave too little variation to identify potentially important correlations. Put differently, the inclusion of country fixed effects decrease the probability of type I errors, or the possibility that we would wrongfully conclude that the proposed theories in the literature indeed explain constitutional review adoption. But the fixed effects actually increase the probability of type 
II errors, whereby we would wrongfully conclude that these theories do not explain constitutional review adoption. ${ }^{50}$ To address this concern, Table 2 , column 4 re-estimates the probit specification from Table 2, column 1 without the country fixed effects. ${ }^{51}$ As can be seen from Table 2, column 4, the results are fairly similar to the baseline specification from column 1 in terms of both size and significance. The only exception is the variable that that captures diffusion through shared borders, which becomes statistically significant only at the 10 percent confidence interval. The similarity of the findings suggests that the fixed effects have not mistakenly caused us to rule out substantively important explanations for constitutional review adoption.

A separate concern with our analysis is that, even though our data covers a large number of countries from 1781 to 2011, we only observe a small number of cases of judicial review adoption. Specifically, due to the onset structure of the dependent variable (in which a country leaves the sample as soon as judicial review has been adopted) we have in our main analysis only 112 observations that take the value " 1 ", while all other observations take the value " 0 ." King and Zeng (2001) show that, in cases like ours when onsets are rare, standard maximum likelihood procedures may substantially underestimate the probability of an event occurring. We therefore use their correction procedure and repeat our baseline specification reported in Table 1, column 1 using their rare event logistic model. The coefficients from this model are reported in Table 3, column 5. The results are very similar to our baseline findings. Using the rare events logit procedure, all coefficients on the variables have the same signs and are significant at the same levels. We therefore conclude that our fixed-effect probit model is an appropriate method for our empirical analysis.

We repeated the same set of robustness checks (i.e, the fixed effects linear probability model; the fixed effects conditional logit model, the random effects probit model, the ordinary probit model and the rare events logit model) for the specification reported in Table 2, column 2, which augments the baseline specification with four additional variables. None of these additional specifications, however, substantially altered the results reported in Table 2, column 2.

While our finding that constitutional review adoption is closely linked to the electoral market is robust to a range of alternative model specifications, there is an open question whether political 
insurance theory is a causal determinant of constitutional review adoption (as opposed to a mere correlation). One conceptual possibility is reversed causality, such that constitutional review affects the political composition of the legislative branch, rather than vice-versa. This scenario, however, seems a highly unlikely one given the temporal sequence we are testing. At the time that any country decides to adopt constitutional review, there is typically no active court already able to alter the political composition of the legislative branch. For the specifications in which we lag the insurance variable forward, there technically may be such a court, although it not obvious that a court would be able to affect the political landscape in its first (or first four) years of operation.

Potentially more problematic than the possibility of reversed causality is the possibility of omitted variable bias. Omitted variable bias would occur if there were an alternative explanation for constitutional review adoption that is related to the political insurance variable but omitted from our analysis. In this case, the effect of this alternative, but omitted, explanation would be attributed to the political insurance variable in our analysis, causing us to overestimate the importance of political insurance.

The concern for potentially important but omitted variables is in part mitigated by our inclusion of country fixed effects, which control for all time-invariant country characteristics. As a result, omitted variable bias could only be caused by time-varying factors. It is possible that such factors indeed do exist. One possible candidate is democracy, which is correlated with demand for political insurance, and potentially also with the adoption of constitutional review (Dworkin 1990). To explore this possibility, we augment the baseline specification from Table 2, column 1 with a democracy variable taken from the Polity IV data project (Gurr et al. 1990). When adding this variable, the political insurance variable is still statistically significant at the 5 percent confidence level, while the democracy variable is statistically significant at the 10 percent confidence level. This finding is reassuring as it suggests that our findings are not in fact driven by the presence of democracy, but by more specific workings of the electoral market instead. Again, this is consistent with the literature on electoral authoritarianism, which suggests that electoral markets also play a role in non-democracies (Schedler 2009). We do not include democracy in our baseline specifications, however, because the existence of constitutional review may be incorporated into the 
various democracy indicators, making it impossible to establish how democracy affects constitutional review adoption. ${ }^{52}$

[COMP: insert Table 3 here]

\section{Conclusion}

Constitutional review has spread around the world in recent decades, and various theories have arisen to account for this development. We have canvassed several different types of theories: (1) ideational theories which view constitutional review adoption as a product of a growing consciousness of the rule-of-law and protection of individual liberties; (2) coordination and commitment theories that draw on functional political logics of federalism and economic growth; (3) electoral market theories that hold that constitutional review is adopted when constitutionmakers envision themselves out of power after the adoption of the constitution; and (4) diffusion theories that posit that constitutional review is adopted in response to international audiences and constitutional developments in foreign states.

Drawing on a new and unique quantitative dataset that documents the development of this institution across the globe since 1781, we used a fixed effects spatial lag model to develop the most extensive empirical test so far of these alternative accounts. Our results provide strong support for the insurance-based theory, and less support for the alternative accounts. The adoption of constitutional review is above all a response to domestic political incentives, rather than ideas, the demands of federalism, or diffusion pressures. The lack of support for diffusion-based accounts is particularly important, given that other work has demonstrated the role of diffusion with regard to constitutional provisions on human rights. We suggest that this reflects the relatively low cost of adopting rights provisions relative to institutional structures in national constitutions. Rights may represent "cheap talk," while institutions are likely to develop a self-enforcing quality so that constitutional designers must treat them as involving higher stakes. 


\section{References}

Acemoglu, Daron and Simon Johnson 2005. Unbundling Institutions. Journal of Political Economy 113(5): 949-95

Ai, Chunrong, and Edward C. Norton. 2003. Interaction Terms in Logit and Probit Models. Economic Letters 80: $123-29$.

Barro, Robert and Rachel M. McCleary. 2005. Which Countries Have State Religions? The Quarterly Journal of Economics 120: 1331-70.

Beck, Nathaniel and Jonathan Katz 2001. Throwing out the Baby with the Bath Water: A Comment on Green, Kim, and Yoon, International Organization 55(2): 487-95.

Beck, Nathaniel, Jonathan N. Katz, and Richard Tucker. 1998. Taking Time Seriously: Times-Series-CrossSection Analysis with a Binary Dependent Variable, American Journal of Political Science 42: 1260-88.

Billias, George Athan. 2010. American Constitutionalism Heard Round the World 1776-1989: A Global Perspective. New York: NYU Press.

Bobbitt, Philip. 2002. The Shield of Achilles: War, Peace, and the Course of History. New York: Random House.

Bogdanor, Vernon. 2009. The New British Constitution. Oxford: Hart Publishing.

Bork, Robert H. 2003. Coercing Virtue: The Worldwide Rule of Judges Everywhere. Washington DC: The AEI Press.

Bosker, Maarten and Joppe de Ree. 2011. Ethnicity and the Spread of Civil War. Manuscript.

Box-Steffensmeier, Janet M., Suzanna de Boef, and Kevin Sweeney. 2005. Multilevel, Stratified, Frailty Models and the Onset of Civil War (manuscript). 
Brady, Paul. Forthcoming. The Social and Political Foundations of The Irish Constitutional Order, in D. Galligan and M. Versteeg, eds., The Social and Political Foundations of Constitutions. New York: Cambridge University Press.

Cappelletti, Mauro. 1989. The Judicial Process in Comparative Perspective. New York: Oxford University Press.

Carter David B. and Curtis S. Signorino. 2010. Back to the Future: Modeling Time Dependence in Binary Data, Political Analysis 18: 271-92.

Chavez, Rebecca Bill. 2004. The Rule-of-law in Nascent Democracies. Stanford: Stanford University Press.

Choper, Jesse. 1980. Judicial Review in the National Political Process: A Functional Reconsideration of the Role of the Supreme Court. Chicago: University of Chicago Press.

Cohen, Patricia. 2010. “In 500 Billion Words, A New Window on Culture.” New York Times, December 17, A3.

Cope, Kevin. 2013. Global Constitutionalism Meets Local Politics: The Making of the World's Youngest Constitution, in D. Galligan and M. Versteeg, eds., The Social and Political Foundations of Constitutions.

Dahl, Robert. 1991. Democracy and Its Critics. New Haven, CT: Yale University Press.

De Tocqueville, Alexis. 1835. Democracy in America. Trans. R.D. Heffner. 2001 ed. New York: New American Library.

de Wet, Erika. 2006. The International Constitutional Order, International \& Comparative Law Quarterly 55: $51-76$.

Dicey, Albert V. 1915. The Law of the Constitution. Indianapolis, IN: Liberty Fund, Inc.

DiMaggio, Paul J., and Walter W. Powell. 1983. The Iron Cage Revisited: Institutional Isomorphism and Collective Rationality in Organizational Fields, American Sociology Review 48: 147-60. 
Dixon, Rosalind and Eric Posner. 2011. The Limits of Constitutional Convergence, Chicago Journal of International Law 11: 399-423.

Dixon, Rosalind and Vicky Jackson. 2012. Outsider Constitutional Interpretation. Manuscript.

Dworkin, Ronald 1990. A Bill of Rights for Britain. Ann Arbour: University of Michigan Press.

Elkins, Zachary, Tom Ginsburg, and James Melton. 2009. The Endurance of National Constitutions. New York: Cambridge University Press.

Elkins, Zachary. 2009. Constitutional Networks, in M. Kahler, ed., Networked Politics: Agency, Power, and Governance. Ithaca, NY: Cornell University Press.

Elkins, Zachary, Andrew Guzman and Beth Simmons. 2006. Competing for Capital: the Diffusion of Bilateral Investment Treaties, 1960-2000, International Organization 60 :811-846.

Elster, Jon. 1993. Majority Rule and Individual Rights, in S. Shute and S. Hurley, eds., On Human Rights: The Oxford Amnesty Lectures. New York: Basic Books.

Erdos, David. 2010. Delegating Rights Protection: The Rise of Bills of Rights in the Westminster World. New York: Oxford University Press.

Farber, Daniel. 2002. Rights as Signals. Journal of Legal Studies 31: 83-98.

Favoreu, Louis. 1990. American and European Models of Constitutional Justice, in D. Clark, ed., Comparative and Private International Law: Essays in Honor of John Merryman. Berlin, Germany: Duncker \& Humbolt.

Feldman, Noah. 2005. Imposed Constitutionalism, Connecticut Law Review 37: 847-73.

Ferejohn, John and Pasquale Pasquino. 2004. Constitutional Adjudication: Lessons from Europe, University of Texas Law Review 82: 1671-1704.

Ferejohn, John and Pasquale Pasquino. 2012. Constitutional Adjudication, Italian Style, in T. Ginsburg, ed., Comparative Constitutional Design. New York: Cambridge University Press. 
Fernández-Val, Iván. 2009. Fixed Effects Estimation of Structural Parameters and Marginal Effects in Panel Probit Models, Journal of Econometrics 150: 71-85.

Finkel, Jodi. 2008. Judicial Reform as Political Insurance: Argentina, Peru and Mexico in the 1990s. Notre Dame, IN: University of Notre Dame Press.

Foley, Kathleen E. 2007. Australian Judicial Review, Washington University Global Studies Law Review 6: 281-338.

Frank, David John, Ann Hironaka, and Evan Schofer. 2000. The Nation-State and the Natural Environment Over the Twentieth Century, American Sociology Review 65: 96-116.

Franzese, Robert J., and Jude C. Hays. 2008. "Empirical Models of Spatial Interdependence.” In Oxford Handbook of Political Methodology, ed. Janet M. Box-Steffensmeier, Henry E. Brady, and David Collier. Oxford: Oxford University Press.

Galligan, Denis and Mila Versteeg. Forthcoming. The Social and Political Foundations of Constitutions: An Introduction, in D. Galligan and M. Versteeg, eds., The Social and Political Foundations of Constitutions.

Gardbaum, Stephen. 2001. The New Commonwealth Model of Constitutionalism, American Journal of Comparative Law 49: 707-60.

Gardbaum, Stephen. 2009. Human Rights and International Constitutionalism, in J. Dunoff and J. Trachtman, eds., Ruling the World? Constitutionalism, International Law and Global Governance. Cambridge: Cambridge University Press.

Garrett, Geofrey and Barry Weingast. 1993. Ideas, Interests, and Institutions: Constructing the European Community's Internal Market. In J. Goldstein and R. O. Keohane, eds., Ideas and Foreign Policy: Beliefs, Institutions, and Political Change. Ithaca, NY: Cornell University Press. pp. 173-206, Ginsburg, Tom and Tamir Moustafa. 2008. Rule By Law: The Politics of Courts in Authoritarian Regimes. Cambridge: Cambridge University Press. 
Ginsburg, Tom. 2003. Judicial Review in New Democracies: Constitutional Courts in Asian Cases. New York: Cambridge University Press.

Gleditsch, Kristian Skrede and Michael D. Ward. 2006. Diffusion and the International Context of Democratization, International Organization 60: 911-33.

Go, Julian. 2003. A Globalizing Constitutionalism? Views from the Postcolony, 1945-2000, International Sociology 18: 71-95.

Goderis, Benedikt and Mila Versteeg. 2011. The Transnational Origins of Constitutions: An Empirical Investigation. Working Paper.

Goodman, Ryan and Derek Jinks. 2004. How to Influence States: Socialization and International Human Rights Law, Duke Law Journal 54: 621-703.

Green, D. P., S. Y. Kim, and D. H. Yoon. 2001. Dirty pool, International Organization 55(2): 441-68.

Gurr, Ted Robert, Keith Jaggers, and Will H. Moore. 1990. The Transformation of the Western State: The Growth of Democracy, Autocracy, and State Power Since 1800, Studies in Comparative International Development 25: 73-108.

Hale, Charles. 2000. The Civil Law Tradition and Constitutionalism in Twentieth-Century Mexico: The Legacy of Emilio Rabasa, Law and History Review 18: 257-80.

Hamilton, Alexander. 1788. The Federalist No. 78, J. and A. McLean.

Hayek, Friedrich. 1960. The Constitution of Liberty. Chicago, IL: University of Chicago Press.

Heckman, James. 1981. The Incidental Parameters Problem and the Problem of Initial Conditions in Estimating a Discrete Time-Discrete Data Stochastic Process, in C. Manski and D. McFadden, eds., Structural Analysis of Discrete Data. Cambridge, MA: MIT Press.

Henisz, Witold J. 2002. The Institutional Environment for Infrastructure Investment, Industrial and Corporate Change 11: 355-89. 
Henkin, Louis, Sarah Cleveland, and Laurence R. Helfer. 2009. Human Rights. Foundation Press.

Hirschl, Ran. 2004. Toward Juristocracy. Cambridge, MA: Harvard University Press.

Hirschl, Ran. 2013. The Strategic Foundations of Constitutions, in D. Galligan and M. Versteeg, eds., The Social and Political Foundations of Constitutions.

Kelsen, Hans. 1928. La Garantie Jurisdictionnelle de la Constitution. Revue de Droit Public 45: 197,

La Porta, Rafael, Florencio Lopez-de-Silanes, Andrei Shleifer and Robert Vishny. 1998. Law and Finance. Journal of Political Economy 106: 1113-55.

Law, David S. and Mila Versteeg. 2011. The Evolution and Ideology of Global Constitutionalism. California Law Review 99: 1163-1257.

Law, David S. and Mila Versteeg. 2012a. The Declining Influence of the United States Constitution. NYU Law Review 87: 762-858.

Law, David S. and Mila Versteeg. 2012c. Sham Constitutions. Manuscript.

Law, David S. and Mila Versteeg. 2012b. Debating the Influence of the United States Constitution. NYU Law Review Online 87.

Law, David S. 2008. Globalization and the Future of Constitutional Rights. Northwestern University Law Review 102: 1277-1350.

Levitsky, Steven and Lucan A. Way. 2010. Competitive Authoritarianism: Hybrid Regimes after the Cold War. New York: Cambridge University Press.

Linos, Katerina. 2011. Diffusion through Democracy, American Journal of Political Science 55: 678-95. Linos, Katerina. 2013. The Democratic Foundations of Policy Diffusion. New York: Oxford University Press. Madsen, Robert A. 2001. The Struggle for Sovereignty Between China and Taiwan, in S. Krasner, ed., Problematic Sovereignty. New York: Columbia University Press. 
Magaloni, Beatriz. 2008. Enforcing the Autocratic Political Order and the Role of Courts: The Case of Mexico, in T. Ginsburg and T. Moustafa, eds., Rule By Law: The Politics of Courts in Authoritarian Regimes. New York: Cambridge University Press.

Magealheas, Pedro C. 2013. Explaining the Constitutionalization of Social Rights: Portuguese Hypotheses and a Crossnational Test, in D. Galligan and M. Versteeg, eds., The Social and Political Foundations of Constitutions.

Mahoney, Paul. 2001. The Common Law and Economic Growth: Hayek Might Be Right, Journal Legal Studies. 30: 502-25.

Marbury v. Madison, 5 U.S. 137 (1803).

Marshall, Monty G., Keith Jaggers, and Ted Robert Gurr. 2010. Polity IV Project Data Users' Manual. http://www.systemicpeace.org/inscr/p4manualv2010.pdf

Merryman, John and Rogelio Pérez-Perdomo. 2007. The Civil Law Tradition, 3rd Edition: An Introduction to the Legal Systems of Europe and Latin America. Palo Alto, CA: Stanford University Press.

Meyer, John W. and Brian Rowan. 1977. Institutionalized Organizations: Formal Structure as Myth and Ceremony, American Journal of Sociology 83: 340-63.

Meyer, John W., John Boli, George Thomas, and Francisco Ramirez. 1997. World Society and the NationState, American Journal of Sociology 103: 144-81.

Michel, Jean-Baptiste, et al. 2010. Quantitative Analysis of Culture Using Millions of Digitized Books, Science 331: 176-82.

Miguel, Edward, Shanker Satyanath, and Ernest Sergenti. 2004. Economic Shocks and Civil Conflict: An Instrumental Variable Approach, Journal of Political Economy 112: 725-53.

Moustafa, Tamir. 2007. The Struggle for Constitutional Power: Law, Politics and Economic Development in Egypt. Cambridge: Cambridge University Press. 
Nardulli, Peter, Buddy Peyton, and Joseph Bajjelieh. 2011. Legal Infrastructure. Manuscript.

North, Douglass and Barry Weingast. 1989. Constitutions and Commitment: The Evolution of Institutions Governing Public Choice in Seventeenth Century England. Journal of Economic History 49(4): 804-32.

O’Neal, J. R., and B. Russett (2001): “Clear and Clean: The Fixed Effects of the Liberal Peace,” International Organization, 55(2), 469-485.

Parkinson, Charles. 2007. Bills of Rights and Decolonization: The Emergence Of Domestic Human Rights Instruments in Britain's Overseas Territories. Oxford: Oxford University Press.

Polillo, Simone and Mauro F. Guillén. 2005. Globalization Pressures and the State: The Worldwide Spread of Central Bank Independence, American Journal of Sociology 19: 1764-1802.

Prakash, Saikrishna and John Yoo. 2003. The Origins of Judicial Review, University of Chicago Law Review 70: 887-982.

Ramseyer, J. Mark. 1994. “The Puzzling (In)dependence of Courts: A Comparative Approach.” Journal of Legal Studies 23:721-747.

Schedler, Andreas. 2009. The New Institutionalism in the Study of Authoritarian Regimes. Centro de Investigación y Docencia Económicas, División de Estudios Políticos, 2009. Working Paper \# 215.

Shapiro, Martin and Alec Stone-Sweet. 2002. On Law, Politics, and Judicialization. New York: Oxford University Press.

Shapiro, Martin. 1964. Law and Politics in the Supreme Court. Glencoe, IL: Free Press of Glencoe. Shapiro, Martin. 2002. The Success of Judicial Review and Democracy, in M. Shapiro and A. Stone Sweet, eds., On Law Politics and Judicialization. Oxford: Oxford University Press.

Shapiro, Martin. 1999. The Success of Judicial Review, in S. Kenny, W. Rieseinger and J. Reitz, eds., Constitutional Dialogues in Comparative Perspective. New York: St. Martin's Press. 
Simmons, Beth A. 2009. Mobilizing for Human Rights: International Law in Domestic Politics. New York: Cambridge University Press.

Simmons, Beth A. and Zachary Elkins. 2004. The Globalization of Liberalization: Policy Diffusion in the International Political Economy, American Political Science Review 98: 171-89.

Simmons, Beth A., Frank Dobbin, and Geoffrey Garrett. 2006. Introduction: The International Diffusion of Liberalism, International Organization 60: 781-810.

Smith, Carsten. 2000. Judicial Review of Parliamentary Legislation: Norway as a European Pioneer. Presented at University of London Annual Coffin Memorial, London, 3 April 2003.

Snowiss, Sylvia. 1990. Judicial Review and the Law of the Constitution. New Haven, CT: Yale University Press.

Stephenson, Matthew. 2003. When the Devil Turns...: The Political Foundations of Independent Judicial Review. Journal of Legal Studies 32: 59-89.

Stone Sweet, Alec. 1992. The Birth of Judicial Politics in France. New York: Oxford University Press.

Stone Sweet, Alec. 1995. Coordinate Construction and Constitutional Development in France and Germany, in C.N. Tate and T. Vallinder, eds., The Global Expansion of Judicial Power. New York: New York University Press.

Stone Sweet, Alec. 2000. Governing with Judges. New York: Oxford University Press.

Stone Sweet, Alec. 2008. Constitutions and Judicial Power, in D. Caramani, ed., Comparative Politics. Oxford: Oxford University Press.

Stone Sweet, Alec. 2012. Constitutional Courts, pp. 816-30 in Michel Rosenfeld and Andras Sajo, The Oxford Handbook of Comparative Constitutional Law. Oxford: Oxford University Press.

Strang, David. 1991. Adding Social Structure to Diffusion Models: An Event History Framework, Sociological Methods and Research 19: 324-53. 
Tamanaha, Brian. Forthcoming. The Battle Between Law and Society in Micronesia, in D. Galligan and M. Versteeg, eds., The Social and Political Foundations of Constitutions. New York: Cambridge University Press.

Treanor, William. 2005. Judicial Review before Marbury, Stanford Law Review 58: 455-562.

Tushnet, Mark. 2003. Weak Courts, Strong Rights: Judicial Review and Social Welfare Rights in Comparative Constitutional Law. Princeton, NJ: Princeton University Press.

Van der Schyff, Gerhard. 2010. Judicial Review of Legislation: Constitutionalism Personified in the UK, Netherlands and S. Africa. Dordrecht: Springer.

Voigt, Stefan, Michael Ebeling, and Lorenz Blume. 2007. Improving Credibility by Delegating Judicial Competence: The Case of the Judicial Committee of the Privy Council, Journal of Development Economics 82: $348-373$.

Weingast, Barry. 1995. The Economic Role of Political Institutions: Market-Preserving Federalism and Economic Development, Journal of Law, Economics \& Organization 11: 1-31.

Weinrib, Lorraine. 2007. The Postwar Paradigm and American Exceptionalism, in S. Choudhry, ed., The Migration of Constitutional Ideas. Cambridge: Cambridge University Press.

Wooldridge, Jeffrey M. 2009. Introductory Econometrics: A Modern Approach. Mason, OH: SouthWestern College Publishers.

Zakaria, Fareed. 2003. The Future of Freedom. New York: W. W. Norton \& Company.

\section{Constitutions}

Argentina Constitution, 1994.

Austria Constitution, 1920.

Canadian Charter of Rights and Freedoms, 1982. 
Chile Constitution, 1980.

China Constitution, 1982.

Colombia Constitution, 1991.

Czechoslovakia Constitution, 1920.

Dominican Republic Constitution, 2010.

Ecuador Constitution, 1929.

Ecuador Constitution, 1945.

Ecuador Constitution, 1946.

Ecuador Constitution, 1996.

El Salvador Constitution, 1886

El Salvador Constitution, 1871.

Guatemala Constitution, 1921.

Guatemala Constitution, 1993.

Honduras Constitution, 1894

Iraq Constitution, 1925.

Lichtenstein Constitution, 1921.

Mexico Constitution, 1824

Mexico Constitution, 1857.

Netherlands Constitution, 1983.

Nicaragua Constitution, 1894.

Niger Constitution, 1960.

Panama Constitution, 1972.

Paraguay Constitution, 1994. 
Portugal Constitution, 1911.

Spain Constitution, 1931.

Switzerland Constitution, 1848.

Trinidad \& Tobago Constitution, 1962.

Uruguay Constitution, 1996. 
Figure 1 Panels A and B: The Spread of Constitutional Review ${ }^{1}$
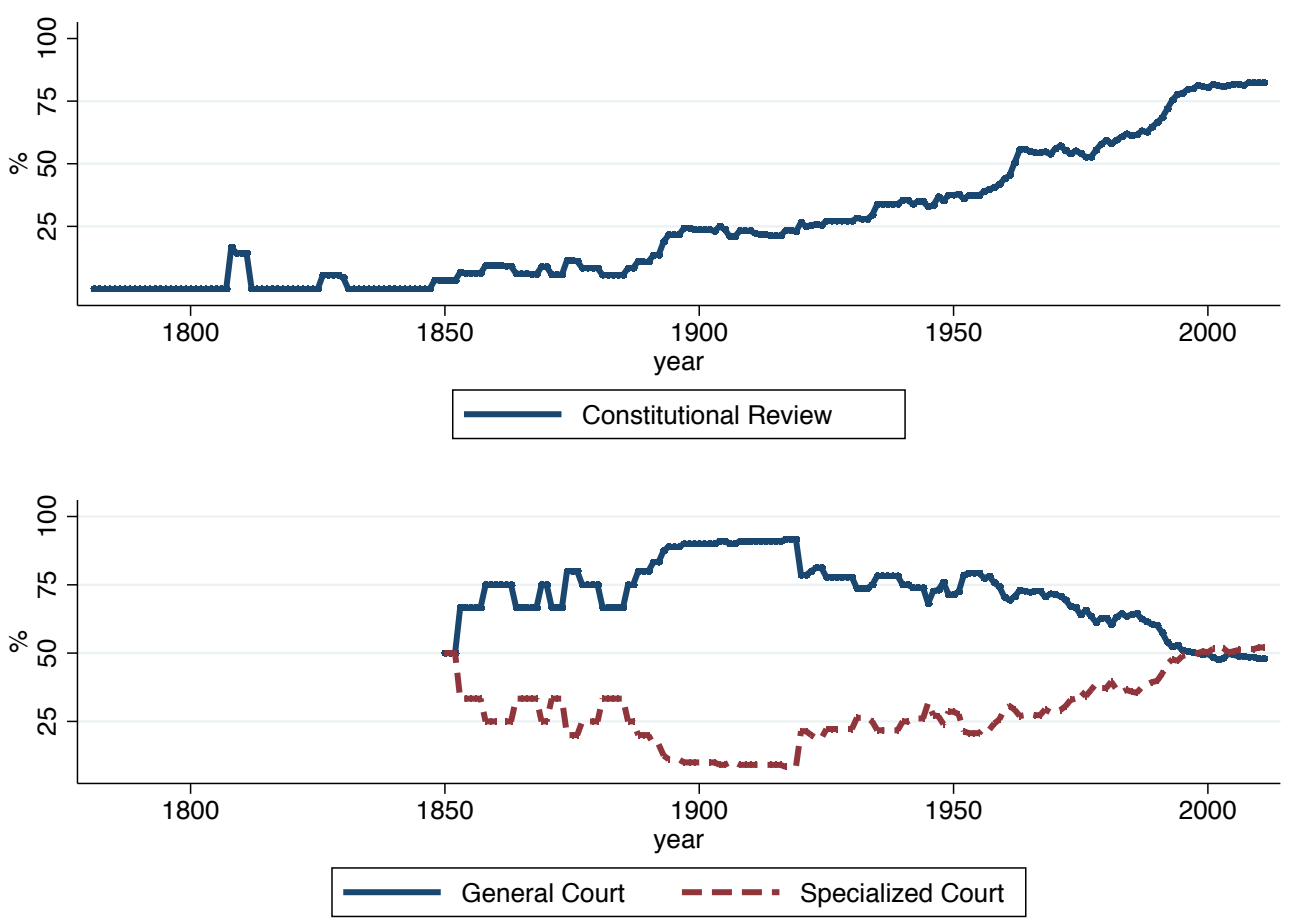

${ }^{1}$ Because there are so few cases of judicial review adoption prior to 1850 , panel B only starts in 1850 , so that we don't show strong fluctuations that do not represent actual trends. 
Table 1: Variables Used in Estimation

\begin{tabular}{lccccc}
\hline & $(1)$ & $(2)$ & $(3)$ & $(4)$ & $(5)$ \\
VARIABLES & Mean & Std. Dev. & Min & Max \\
\hline & & & & & \\
Dependent Variable: Adoption of Constitutional Review & 4565 & 0.025 & 0.155 & 0 & 1 \\
Political Insurance & 4565 & 0.829 & 0.327 & 0 & 1 \\
Diffusion: Shared Religion & 4565 & 0.152 & 0.195 & 0 & 1 \\
Diffusion: Common Legal Origin & 4565 & 0.158 & 0.201 & 0 & 0.818 \\
Diffusion: Common Colonizer & 4565 & 0.165 & 0.225 & 0 & 0.864 \\
Diffusion: Common Border & 4565 & 0.238 & 0.319 & 0 & 1 \\
Diffusion: Shared Language & 4565 & 0.192 & 0.237 & 0 & 1 \\
Time & 4565 & 133.389 & 52.749 & 1 & 227 \\
Time Squared & 4565 & 20574 & 13762 & 1 & 51529 \\
Time Cubed & 4565 & 3457127 & 3033891 & 1 & $1.170 \mathrm{e}+07$ \\
Legal Publications Per Capita & 3400 & 0.015 & 0.024 & 0 & 0.183 \\
Law Schools Per Capita & 3400 & 0.036 & 0.031 & 0 & 0.155 \\
Energy consumption per capita & 3400 & 0.0134 & 0.0243 & 0 & 0.155 \\
Federal System & 3400 & 0.155 & 0.362 & 0 & 1 \\
& & & & & \\
\hline
\end{tabular}


Table 2: Results from Fixed Effects Probit Regressions

(1)

(2)
(3)

(4)

(5)

$(6)$
FE Probit- FE Probit- FE Probit- FE ProbitFE Probit FE Probit Democracy Autocracy Insurance $\mathrm{t}+1$ Insurance $\mathrm{t}+4$

\begin{tabular}{|c|c|c|c|c|c|c|}
\hline Political Insurance & $\begin{array}{c}-0.009 * * \\
(0.003)\end{array}$ & $\begin{array}{c}-0.003 * * \\
(0.002)\end{array}$ & $\begin{array}{c}-0.000 * * \\
(0.000)\end{array}$ & $\begin{array}{c}-0.029 * * * \\
(0.010)\end{array}$ & & \\
\hline Political Insurance $\mathrm{t}+1$ & & & & & $\begin{array}{c}-0.013 * * * \\
(0.003)\end{array}$ & \\
\hline Political Insurance $t+4$ & & & & & & $\begin{array}{c}-0.010^{* * *} \\
(0.003)\end{array}$ \\
\hline Diffusion: Shared Religion & $\begin{array}{c}0.012 \\
(0.011)\end{array}$ & $\begin{array}{c}0.001 \\
(0.004)\end{array}$ & $\begin{array}{c}0.000 * * * \\
(0.000)\end{array}$ & $\begin{array}{c}0.002 \\
(0.026)\end{array}$ & $\begin{array}{c}0.008 \\
(0.009)\end{array}$ & $\begin{array}{c}0.009 \\
(0.010)\end{array}$ \\
\hline Diffusion: Common Legal Origin & $\begin{array}{c}0.011 \\
(0.011)\end{array}$ & $\begin{array}{c}0.002 \\
(0.004)\end{array}$ & $\begin{array}{c}0.000 \\
(0.000)\end{array}$ & $\begin{array}{c}0.023 \\
(0.029)\end{array}$ & $\begin{array}{c}0.005 \\
(0.008)\end{array}$ & $\begin{array}{c}0.014 \\
(0.010)\end{array}$ \\
\hline Diffusion: Common Colonizer & $\begin{array}{c}0.006 \\
(0.009)\end{array}$ & $\begin{array}{l}-0.003 \\
(0.003)\end{array}$ & $\begin{array}{l}0.000^{* *} \\
(0.000)\end{array}$ & $\begin{array}{r}-0.014 \\
(0.31)\end{array}$ & $\begin{array}{c}0.006 \\
(0.008)\end{array}$ & $\begin{array}{c}0.003 \\
(0.008)\end{array}$ \\
\hline Diffusion: Common Border & $\begin{array}{c}0.003 \\
(0.004)\end{array}$ & $\begin{array}{c}0.001 \\
(0.002)\end{array}$ & $\begin{array}{c}-0.000 \\
(0.000)\end{array}$ & $\begin{array}{l}-0.009 \\
(0.010)\end{array}$ & $\begin{array}{c}0.003 \\
(0.004)\end{array}$ & $\begin{array}{c}0.002 \\
(0.004)\end{array}$ \\
\hline Diffusion: Shared Language & $\begin{array}{l}-0.008 \\
(0.011)\end{array}$ & $\begin{array}{c}0.001 \\
(0.003)\end{array}$ & $\begin{array}{l}-0.000 \\
(0.000)\end{array}$ & $\begin{array}{c}0.033 \\
(0.034)\end{array}$ & $\begin{array}{l}-0.007 \\
(0.008)\end{array}$ & $\begin{array}{l}-0.007 \\
(0.010)\end{array}$ \\
\hline Time & $\begin{array}{l}-0.000 \\
(0.000)\end{array}$ & $\begin{array}{l}0.001 * * \\
(0.001)\end{array}$ & $\begin{array}{c}0.000 \\
(0.000)\end{array}$ & $\begin{array}{c}0.001 \\
(0.001)\end{array}$ & $\begin{array}{l}-0.000 \\
(0.000)\end{array}$ & $\begin{array}{l}-0.000 \\
(0.000)\end{array}$ \\
\hline Time Squared & $\begin{array}{c}0.000 \\
(0.000)\end{array}$ & $\begin{array}{l}0.000^{* *} \\
(0.000)\end{array}$ & $\begin{array}{l}-0.000 \\
(0.000)\end{array}$ & $\begin{array}{l}-0.000 \\
(0.000)\end{array}$ & $\begin{array}{c}0.000 \\
(0.000)\end{array}$ & $\begin{array}{c}0.000 \\
(0.000)\end{array}$ \\
\hline Time Cubed & $\begin{array}{l}-0.000 \\
(0.000)\end{array}$ & $\begin{array}{c}-0.000 * * \\
(0.00)\end{array}$ & $\begin{array}{l}0.000 \\
(0.00)\end{array}$ & $\begin{array}{l}0.000 \\
(0.00)\end{array}$ & $\begin{array}{l}-0.000 \\
(0.000)\end{array}$ & $\begin{array}{l}-0.000 \\
(0.000)\end{array}$ \\
\hline Legal Publications Per Capita & & $\begin{array}{l}0.027^{*} \\
(0.022)\end{array}$ & & & & \\
\hline Law Schools Per Capita & & $\begin{array}{l}-0.029 \\
(0.033)\end{array}$ & & & & \\
\hline Energy Consumption Per Capita & & $\begin{array}{l}-0.000 \\
(0.000)\end{array}$ & & & & \\
\hline Federal System & & $\begin{array}{c}0.009 \\
(0.014)\end{array}$ & & & & \\
\hline Observations & 4564 & 3400 & 885 & 2142 & 4562 & 4550 \\
\hline (pseudo) R-squared & 0.25 & 0.28 & 0.58 & 0.23 & 0.26 & 0.25 \\
\hline LR Test $\left(\right.$ Prob $\left.>\mathrm{Chi}^{\wedge} 2\right)$ & 0.000 & 0.000 & 0.000 & 0.000 & 0.000 & 0.000 \\
\hline Country Effects & Yes & Yes & Yes & Yes & Yes & Yes \\
\hline
\end{tabular}

Marginal effects from fixed effects probit regression (with all regressors evaluated at their sample mean)

Robust standard errorsclustered at country-level in parentheses
$* * * \mathrm{p}<0.01, \quad * * \mathrm{p}<0.05, \quad * \mathrm{p}<0.1$ 
Table 3: Robustness checks

(1)

(2)

(3)

(4)

(5)

Fixed- Fixed-Effects Random

Effects Conditional Effects

LPM Logit Probit

Political Insurance

$-0.036 * *$

$(0.015)$

Diffusion: Shared Religion

$0.094 * *$

(0.036)

0.081

(0.049)

0.050

(0.041)

0.008

(0.015)

$-0.049$

(0.059)

$-0.000$

(0.000)

Time Squared

Time Cubed

0.000

(0.000)

$-0.000$

(0.000)

$-1.355 * *$

(0.776)

2.892

(2.258)

2.245

(2.217)

0.798

(2.275)

0.573

$(0.765)$

$-1.828$

(2.511)

0.021

(0.121)

$-0.00$

(0.000)

$-0.00$

(0.00)

4,969

0.38

0.000

(pseudo) R-squared

LR Test (Prob $>\mathrm{Chi}^{\wedge}{ }^{\wedge}$ )

Country Effects

Spatial Weights

Yes

No

Standard errors in parentheses

$* * * \mathrm{p}<0.01, * * \mathrm{p}<0.05, * \mathrm{p}<0.1$

\begin{tabular}{ccc}
$\begin{array}{c}\text { Effects } \\
\text { Probit }\end{array}$ & Probit & $\begin{array}{c}\text { Rare Event } \\
\text { Logit }\end{array}$ \\
\hline & & \\
$-0.599 * * *$ & $-0.018 * *$ & $-1.351^{* *}$ \\
$(0.193)$ & $(0.007)$ & $(0.657)$ \\
0.237 & -0.003 & 2.849 \\
$(0.418)$ & $(0.015)$ & $(2.673)$ \\
0.970 & 0.030 & 2.074 \\
$(0.677)$ & $(0.024)$ & $(2.119)$ \\
0.368 & 0.009 & 0.802 \\
$(0.467)$ & $(0.017)$ & $(2.238)$ \\
$0.390 *$ & $0.014 *$ & 0.584 \\
$(0.204)$ & $(0.008)$ & $(0.786)$ \\
$-0.680 *$ & -0.020 & -1.780 \\
$(0.412)$ & $(0.017)$ & $(2.586)$ \\
-0.009 & -0.000 & 0.006 \\
$(0.024)$ & $(0.000)$ & $(0.133)$ \\
0.000 & 0.000 & -0.00 \\
$(0.000)$ & $(0.000)$ & $(0.000)$ \\
-0.00 & -0.000 & -0.00 \\
$(0.00)$ & $(0.00)$ & $(0.00)$ \\
& & \\
\hline 4,969 & 4969 & 4656 \\
- & 0.23 & - \\
- & 0.000 & - \\
No & No & Yes \\
Yes & Yes & No \\
\hline
\end{tabular}

4,338

0.12

$-$

No

No

Yes

Yes 
${ }^{1}$ Constitutional review is technically a subcategory of judicial review, which also includes review of administrative
action for conformity with a statute or the constitution, although the terms are often used interchangeably in the
literature. We include in our consideration all courts located within a country whose jurisdiction extends over the nation
or some part thereof. We use the term local court to distinguish systems in which the only review body is external to the
country, such as commonwealth countries whose only institution for review is the Privy Council in London. See
discussion in Part 4.B below.

${ }^{2} \mathrm{He}$ argued, for example, that the Constitution can be "preserved in practice no other way than through the medium of courts of justice, whose duty it must be to declare all acts contrary to the manifest tenor of the Constitution void."

${ }^{3}$ As the U.S. Supreme Court has noted "[i]t is a basic principle of Article III [of the Constitution] that a justiciable case or controversy must remain extant at all stages of review." See Arizonans for Official English v. Arizona, 520 U.S. 43, 67 (1997).

${ }^{4}$ Interestingly, a brief experiment of what would today be called a constitutional court took place in the Netherlands between 1802 and 1805. During this time a body comprising three members of the judiciary, called the National Syndicate, exercised centralised constitutional review (van der Schyff, 1975).

${ }^{5}$ This form of review, exercised over the course of litigation, is typically considered to be "concrete," but it is still more "abstract" than review in the American system, as the constitutional court decides the constitutional question in the abstract, not in the context of the lower court's specific dispute.

${ }^{6}$ Many French colonies have not yet updated their model to keep pace with the developments in the metropole, so that the distinct French model of pre-promulgation review remains alive and well.

${ }^{7}$ We recognize that the conceptual distinctions among these theories are not watertight. For example, the coupling of rights and constitutional review might serve a strategic purpose when rights align with the interests of political elites, as was arguably the case in postwar Europe (Stone Sweet 2000). The same might potentially be true for the link between federalism and rights. Our categorization is simply designed to provide an overview of the existing literature.

${ }^{8}$ Some accounts of the growth of judicial review at the supranational level, and particularly within the European Court of Justice, also portray judicial review as a response to complex coordination problems deriving from the systemic need to adopt standardized legal norms and administrative regulations across member-states in an era of converging economic markets (Stone-Sweet 2000).

${ }^{9}$ In Hirschl's (2004) account, losing elites typically entrench neo-liberal values, protecting property and the free market, but there are also competing accounts that suggest that the judiciary is likely to protect the values of the cosmopolitan left (Bork 2003). Ginsburg (2003) does not make any assumptions about the particular kind of values that are likely protected through judicial review.

${ }^{10}$ We use temporally lagged, rather than contemporaneous, spatial lags to avoid so-called "simultaneity bias," which would prevent us from identifying the direction of influence (Brueckner 2003). To avoid this bias, we temporally lag the spatial lags by one year. Lagging by one year eliminates simultaneity only if two conditions are satisfied. First, the error terms should not be subject to first-order serial correlation. And second, the adoption of constitutional review by country $j \neq i$ in year $t-1$ should not directly depend on the adoption of that provision by country $i$ in the (subsequent) year $t$. Because it is not obvious that these two conditions for the elimination of simultaneity are satisfied, we also estimate all specifications using lags that are temporally lagged by five years instead of one. When doing so, results are largely similar to the main model. 
${ }^{11}$ The fixed effects probit runs into the well-documented "incidental parameters problem": for a fixed number of withingroup observations and a growing number of groups, the fixed effects cannot be estimated consistently. We do not think that the incidental parameters problem is a major concern for our analysis. First, the incidental parameters problem is most pronounced in large N, small $\mathrm{T}$ data sets (Heckman 1981), while it is less of a concern in datasets with long timeseries, such as ours (from 1781-2011). Second, we report marginal effects, and a recent study shows that even where the estimated coefficients of the fixed effects probit model might be biased, the bias for the marginal effects tends to be negligible (Fernández-Val 2009). However, to make sure that our choice of the fixed effects probit model is not driving our results, we re-estimate the baseline specification with a fixed effects conditional logit model, which does not suffer from the incidental parameters problem. When doing so, results are virtually identical (see section 6 infra). A possible drawback of the conditional logit specification, however, is that it does not allow us to calculate marginal effects, making it impossible to say anything about the substantive importance of each of the different theories of constitutional review adoption. Following Goderis \& Versteeg (2011), moreover, we re-estimate all findings with a linear probability model, which yields results similar to the fixed effects probit model. For a recent application of the fixed effects probit model as used in our baseline analysis see Bosker and De Ree 2011. For further discussion on how our model specification might affect our findings, see section 6 infra.

${ }^{12}$ Our probit "onset" model is the same as a duration model in which the baseline hazard is considered to be duration independent (meaning that the likelihood of adoption does not increase over time). For constitutional review adoption, however, it seems plausible that probability of adoption will increase with time, as countries might be more prone to adopt institutions that have been around longer. This suggests that we have to account for duration dependence in our model. The literature has proposed different ways of doing so. One option would be to use an event history framework, which is most sophisticated if it comes to modelling duration dependence (see Elkins et al., 2009 for an application). The downside of the event history framework is that it is less intuitive and also less flexible than an ordinary probit regression. Therefore, we model duration dependence using an ordinary probit model (Box-Steffensmeier et al. 2005). The most common way of doing so is to include time dummies for each time period since an event has taken place (Beck et al. 1998). Though intuitive, this time dummy approach performs poorly when $\mathrm{N}$ is relatively small and $\mathrm{t}$ is relatively large (see Carter \& Signorino 2010, reporting, based on Monte Carlo simulations, that time dummies perform poorly if $\mathrm{N}<1000$ and $\mathrm{t}>15$ ). An alternative approach to modelling time in a duration framework, which does not run into these problems, is through inclusion of natural cubic splines. While easy to implement, this approach requires some non-straightforward modelling decisions. Perhaps most importantly, the cubic splines do not lend themselves to straightforward empirical interpretation. Following recent methodological insights by Carter and Signorino (2010), we simply account for time by putting in cubic polynomials $t, t^{2}$ and $t^{3}$, which are equivalent to the inclusion of natural splines. For sensitivity we also re-estimated our findings with several duration models: a semi-parametric Cox proportional hazards model, a parametric exponential hazards model and a parametric Weibull hazard model. In all these cases, the results are similar to those obtained from the probit model with cubic splines.

${ }^{13}$ A recent example of such transnational constitutional review was a decision by the East African Court of Justice that Kenya's election rules violated the Treaty Establishing the East African Community. (Peter Anyang' Nyong'o v. Attorney General of Kenya (2006) (East African Court of Justice)).

${ }^{14}$ More generally, our definition of constitutional review excludes review based solely on the European Convention on Human Rights and Fundamental Freedoms (ECHR). Some European Constitutions (e.g. Netherlands Constitution of 1983) do not allow for constitutional review, yet nonetheless allow local courts to review statutes for compatibility with the ECHR. In an unreported robustness check, we found that adjusting our coding to provide that all ECHR signatories possess constitutional review from the moment they signed the treaty does not affect our results.

${ }^{15}$ Today, eight independent nations retain the appeal to "Her Majesty in Council," who will then refer the case to the judicial committee of the Privy Council. These are Antigua and Barbuda, the Bahamas, Grenada, Jamaica, St. Kitts and Nevis, St. Lucia, St. Vincent and the Grenadines, and Tuvalu. Four other states, Dominica, Mauritius, Trinidad and 
Tobago, and Kiribati retain appeal directly to the Committee. Brunei uses the Judicial Committee as well, though it is advisory to the Sultan, who is the head of state.

${ }^{16}$ The commonwealth countries with nearly identical Bills of Rights, with largely similar provisions on constitutional review, include Antigua and Barbuda, Bahamas, Barbados, Belize, Botswana, Dominica, Gambia, Grenada, Guyana, Jamaica, Kenya, Kiribati, Lesotho, Malawi, Malta, Mauritius, Nigeria, Samoa, Seychelles, Sierra Leone, Solomon Islands, St. Kitts and Nevis, St. Lucia, St. Vincent and the Grenadines, Swaziland, Trinidad and Tobago, Uganda, Vanuatu, Zambia, and Zimbabwe. For a historical explanation of these similarities see Parkinson (2007).

${ }^{17}$ If we adjust our coding to omit appeal to the Privy Council from cases of constitutional review, our findings are largely similar to those reported in the analysis below, though a little less significant (specifically, the political insurance variable is significant at the 10 percent confidence level instead of the 5 percent confidence level for the baseline model reported in Table 2, column 1).

${ }^{18}$ Indeed, only one of the 11 current members, Jacques Barrot, lacks any prior legal experience.

19 Two cases in 1992 are considered to be exemplary in the development of constitutional rights because they found implied rights. See Nationwide News Proprietary v. Wills (1992) H.C.A. 46 and Australian Capital Television Proprietary Ltd. v. Commonwealth (1992) H.C.A. 45.

${ }^{20}$ If we recode these countries as possessing constitutional review, the results are substantively identical.

${ }^{21}$ Most of our empirical analysis is based on a more limited number of countries, however, due to the availability of the explanatory variables. Our baseline specification includes 135 countries.

${ }^{22}$ We experimented with the new ngram tool by Google that, according to Science magazine, is "revolutionizing the humanities," and has provided the impetus for a new academic field "culturonomics"(Cohen 2010; Michel et al. 2010). The tool allows the user to search billions of digitized literary works in 7 major languages (English, Chinese, Hebrew, French, Russian, Spanish and German). We hypothesized that the frequency of references to the term "human rights" in the literary works written in each language would be a proxy for the "rights-consciousness" of users of that language. We had to abandon this proxy after consultation with the Google ngram team because of the limited availability of books in languages other than English.

${ }^{23}$ Because data on population size is only available from 1950 onwards, we calculate the average population size for the period 1950-2010 and use this as the weight.

${ }^{24}$ We could have used a variable that captures whether any given country has a common law system as a proxy for a rule of law tradition, since many believe that the common law tradition is characterized by a high respect for the rule of law (see Hayek 1960). Yet we believe that the number of law schools per capita and the number of legal publications per capita are better proxies for a rule of law tradition. Moreover, a common law variable is collinear with the fixed effects in our model, which means that the effect of the common law system can only be estimated when we omit the fixed effects. In the specification that does include the common law variable (reported in Table 2, column 4), it is not a statistically significant predictor of constitutional review adoption.

${ }^{25}$ In particular, we use the "cent" variable in the Polity III dataset, which covers 177 countries from 1800 to 1994. (Although there exists a more recent "Polity IV" iteration of this dataset, the newer iteration lacks the data on federalism used here.) The manner in which this variable is coded divides countries into the following three categories: (1) a "Unitary State" category, in which regional units have little or no independent decision-making authority; (2) an "Intermediate" category; and (3) a "Federal State" category, in which most or all regional units have substantial decision-making authority. We consider a country to be federal when it falls into the third category. 
${ }^{26}$ This data is available for the period 1816-2002.

${ }^{27}$ We should note, however, that with our research design, we are not actually able to test the credible commitment theories; the economic development measure is merely likely to be correlated with them.

${ }^{28}$ The Henisz data is available from 1800-2007 for up to 139 countries. For a description of the variables see Henisz (2002). In 25 cases, this electoral data was not available at the time the first constitution was adopted. In these cases, we interpolate the existing data backwards. This means we assume that the constitution-makers foresaw the composition of seats in the legislative branch after the first election. A case can probably be made that constitution-makers indeed have some information on who is likely to win the first elections, even though these elections have not yet taken place (Ginsburg 2003). When we re-estimate our baseline model without these 25 observations, the results are the substantially identical, suggesting that our results do not depend on our assumption for these few cases.

${ }^{29} \mathrm{We}$ use four years as it is the modal fixed term for a legislature. In a previous iteration of this paper we also attempted to separately operationalize Ran Hirschl's hegemonic self-preservation theory, but found the theory difficult to test in a large-N framework. Operationalizing hegemonic preservation would involve assigning an arbitrary cut-off to establish when a party had a "hegemonic" interest to preserve, and had foresight about an eventual electoral loss. Any variable for hegemonic preservation would also likely be collinear with our political insurance variable. We therefore decided to omit the theory from the analysis that follows, and focus on political insurance instead.

${ }^{30}$ This indicator is created from the CEPPII Distance Dataset. http://www.cepii.fr/anglaisgraph/bdd/distances.htm

31 To address potential problems of non-stationarity, we 'row-standardize' the spatial weights matrices (as commonly done in spatial econometrics) by dividing each weight by the sum of weights. As a result, the spatial lags can be viewed as weighted averages.

${ }^{32}$ Data comes from the CEPPII Distance Dataset.

${ }^{33}$ The Barro and McCleary dataset contains information on the prevalence of different religions in both 1970 and 2000. For our baseline estimation we use 1970 data, while we use the 2000 data to test the robustness of our results.

${ }^{34}$ Data for both measures comes from the CEPPII Distance Dataset.

${ }^{35}$ The numbers in Table 1 are based on the baseline model reported in Table 2, column 1, for all variables save "Legal Publications Per Capita," "Law Schools Per Capita," and "Federal System," which are based on the specification in Table 2, column 2.

${ }^{36}$ To obtain marginal effects, we set all the variables at their mean value.

${ }^{37}$ Calculating the baseline probability as the mean predicted value (as opposed to the predicted value at the sample means) does not substantively change the exposition. The baseline probability of adoption in the mean predicted value specification is $2.5 \%$.

${ }^{38}$ These numbers are calculated as $\sum_{t=\bar{t}}^{\bar{t}+20} F\left(\rho \sum_{j \neq i} \overline{\left(W_{l j t-1} \times y_{j t-1}\right)}+\beta \bar{X}_{i t}+\bar{\alpha}_{i}+\bar{\delta}_{t}\right)$ (where an overbar denotes a mean value). Since we do not report the probit coefficients, calculations are available from the authors on request.

${ }^{39}$ The correlations between the different spatial lags are relatively high and range from 0.50 to 0.77 . We therefore tested whether the spatial lags might be jointly significant. We found that the spatial lags are not jointly significant in our baseline specification, although they do become jointly significant in a few of the other specifications reported in Tables 
2 and 3. Results and calculations are available from the authors upon request. We also tested whether the diffusion effect might be confined to the post WWII period, by re-estimating our baseline model for two subsamples covering the pre- and post WWII period. We did not find any significant difference between the two periods.

${ }^{40}$ The correlation between the number of law schools per capita and the number of legal publications per capita is only 0.38 , as a result of which we consider it appropriate to include both variables in the same specification.

${ }^{41}$ The federalism variable varies over time, as countries sometimes move from a centralized government system to federalism, and vice-versa. Because such changes occur only infrequently, there is some concern that the inclusion of this variable in a fixed effects model will leave too little variation to find any effects of federalism. We therefore estimated the same specification without fixed effects, and found that federalism was still not a statistically significant predictor of constitutional review adoption.

${ }^{42}$ The finding, however, is not very robust to alternative model specification, as discussed in the robustness analysis.

${ }^{43}$ We consider a country to be democratic if it has a score of 4 or higher on the polity 2 democracy variable from the polity IV data project, which is a threshold that is commonly used in the literature.

${ }^{44}$ Columns 3 and 4 again report marginal effects when evaluating all variables at their mean. We opt to estimate two subsamples of democratic countries and autocratic countries rather than work with an interaction term because of the problems associated with interaction terms in non-linear models (Ai and Norton 2003).

${ }^{45} \mathrm{We}$ also explored whether the dynamics of constitutional review adoption were different for centralized and decentralized review. Specifically, we estimate two specifications with alternative versions of the dependent variable that capture constitutional review by a specialized constitutional court (either of the Kelsenian or the French centralized variant) or by the general judiciary (the American decentralized variant), respectively. In these models, the spatial lags are adjusted, so that they also only capture the previous adoption of the centralized and decentralized model of constitutional review, respectively. These results suggest that there are no important differences between the two types of constitutional review.

${ }^{46}$ When using the linear probability model, the spatial lag capturing constitutional review adoption by countries with the same dominant religion is also a statistically significant and positive predictor of constitutional review adoption, although this finding is not robust to alternative specifications.

${ }^{47}$ See infra note 50 for an explanation why we have fewer observations in the probit model.

${ }^{48}$ The random effects probit model (which excludes the country fixed effects) includes the dimension along which foreign countries are weighted as a separate variable. Thus, as an example, this specification does not only include the spatial lag that captures adoption by countries with the same legal origin, but also a set of binary variables for each of the different legal origins on which the spatial weights were based. That way, we distinguish a true interdependence among common law countries, for example, from other features of the common law tradition that may make these countries more likely to adopt constitutional review.

49 The size of the marginal effects of the random effects probit model are larger than in the baseline fixed effects specification, which probably results from the fact that a random effects model does not fully account for unobserved cross-country heterogeneity.

${ }^{50}$ For an overview of the debate on the desirability of fixed effects compare Green, Kim and Yoon 2001 with Beck and Katz 2001 and O'Neal and Russett 2001. Another possible problem with the fixed effects approach, which is specific to models with a binary dependent variable, is that we effectively remove from the analysis all the countries that never 
adopted constitutional review, thereby limiting our estimation to those which do. This explains the lower number of observations of the probit model reported in Table 2, column 1 than for the LPM model in Table 2, column 2.

${ }^{51}$ Instead of the fixed-effects, this specification includes a set of dummy variables for each of the dimensions along which foreign countries were weighted in the spatial lags, which were previously controlled for by the fixed effects. See supra note 48.

${ }^{52}$ For example, the democracy variable from the Polity IV data project includes a measure of executive constraints as one of it components, which "refers to the extent of institutionalized constraints on the decision-making powers of chief executives, whether individuals or collectivities" that are imposed by "accountability groups" such as: councils of nobles or powerful advisors in monarchies; the military in coup-prone polities; and in many states a strong, independent judiciary" (Marshall et al. 2010: 24 ). 